\title{
MANAJEMEN PENGEMBANGAN KOMPETENSI GURU UNTUK IMPLEMENTASI KURIKULUM 2013 DI SMA NEGERI PILOT PROJECT YOGYAKARTA
}

\author{
Khotim Hanifudin Najib 1 *, Pardjono 2 \\ 1 Universitas Sarjanawiyata Tamansiswa Yogyakarta, ${ }^{2}$ Universitas Negeri Yogyakarta \\ 1Jl. Batikan UH-III/1043 Yogyakarta 55167, Indonesia \\ 2J1. Colombo No. 1, Depok, Sleman 55281, Yogyakarta, Indonesia \\ * Corresponding Auhtor. Email: khotimhanifudinnajib@yahoo.co.id
}

\begin{abstract}
Abstrak
Penelitian ini bertujuan untuk menggambarkan manajemen pengembangan guru untuk implementasi kurikulum 2013 di SMA Negeri Pilot Project Yogyakarta. Studi ini merupakan penelitian kualitatif dengan metode studi kasus. Penelitian dilakukan di SMA N 2 dan SMAN 8 kota Yogyakarta. Teknik pengumpulan data: observasi, penelusuran dokumen, dan wawancara. Hasil penelitian menunjukkan: (1) perencanaan dilakukan dengan meninjau peraturan menteri pendidikan nasional tentang Kurikulum 2013. (2) pengorganisasian dilakukan oleh kepala sekolah dengan membentuk sebuah tim. (3) pelaksanaan dalam bentuk workshop, pelatihan dan pengembangan, pendidikan dan pelatihan, In-House Training, MGMP, serta studi lebih lanjut. (4) pengendalian dilakukan dengan supervise oleh kepala sekolah. (5) Faktor pendukung pengembangan kompetensi guru adalah: pertama, keberadaan guru yang telah menjadi instruktur nasional pelaksanaan Kurikulum 2013. Kedua, guru memiliki motivasi yang tinggi untuk mengikuti program pengembangan kurikulum ini. Ketiga, sekolah menyediakan anggaran untuk pelaksanaan program pengembangan. Faktor penghambatnya adalah; pertama, peserta program tidak mendapatkan gaji. Kedua, kendala teknis seperti proyektor rusak. Ketiga, perencanaan waktu pelaksanaan agar tidak mengganggu kegiatan pembelajaran di sekolah.
\end{abstract}

Kata kunci: manajemen, pengembangan SDM, implementasi Kurikulum 2013

\section{MANAGEMENT OF TEACHERS COMPETENCE DEVELOPMENT FOR THE IMPLEMENTATION OF CURRICULUM 2013 AT PILOT PROJECT STATE SENIOR HIGH SCHOOL OF YOGYAKARTA}

\begin{abstract}
This study aims to describe the management of the development of teachers for curriculum implementation in 2013 at the pilot project of state senior high school of Yogyakarta. This study is a qualitative research in methods of case studies. Research conducted at the SMA N 2 and SMAN 8 Yogyakarta. Data collection techniques: direct observation, review or archive documents and interviews. The results showed: (1) planning is done by reviewing the regulation of the Minister of national education about curriculum 2013. (2) organizing is done by the head of the school by forming a team. (3) the implementation in the form of workshops, training and development, education, and training, in-house Training, MGMP, as well as further study. (4) Controlling is done by supervising by school principals. (5) supporting the development of teacher competence Factors are: first, the existence of a teacher who has become a national instructor curriculum implementation of 2013. Second, teachers have a high motivation to follow this curriculum development program. Third, schools provide a budget for the implementation of development programs. Inhibiting factor are; First, program participants get no salary. Second, the technical barriers such as the projector is broken. Third, planning implementation time so as not to interfere with learning activities at school.
\end{abstract}

Keywords: management, human resource development, the implementation of Curriculum 2013

Permalink/DOI: http://dx.doi.org/10.21831/amp.v7i1.9525 


\section{Pendahuluan}

Kurikulum merupakan salah satu komponen dalam sistem pendidikan yang sifatnya dinamis, dalam arti dapat dilakukan perubahan dan pengembangan agar dapat mengikuti perkembangan dan tantangan zaman (Mulyasa, 2015, p. 59). Zaman yang terus berkembang dan mengalami perubahan menuntut sekolah mampu mengimbanginya. Kompetensi dan keterampilan yang harus dimiliki oleh peserta didik pun harus di sesuaikan dengan perkembangan zaman. Misalkan perkembangan Information Technology (IT), dahulu pendidikan belum banyak yang memanfaatkannya. Namun saat ini, hampir setiap instansi pendidikan dituntut menggunakannya, baik dalam pembelajaran maupun dalam pengembangan organisasi.

Awal tahun ajaran baru 2013/2014, tepatnya tanggal 15 Juli 2013 sistem pendidikan Indonesia menerapkan kurikulum baru, sebagai pengembangan dari kurikulum sebelumnya, yakni Kurikulum 2013. Perubahan kurikulum tersebut bukan tanpa dasar, melainkan hasil evaluasi perubahan secara global. Tiga faktor yang menjadi alasan pengembangan Kurikulum 2013 adalah, pertama, tantangan masa depan di antaranya meliputi arus globalisasi, masalah lingkungan hidup, kemajuan teknologi informasi, konvergensi ilmu dan teknologi, dan ekonomi berbasis pengetahuan. Kedua, kompetensi masa depan yang di antaranya meliputi kemampuan berkomunikasi, kemampuan berpikir jernih dan kritis, kemampuan mempertimbangkan segi moral suatu permasalahan, kemampuan menjadi warga negara yang efektif, dan kemampuan mencoba untuk mengerti dan toleran terhadap pandangan yang berbeda. Ketiga, fenomena sosial yang mengemuka seperti perkelahian pelajar, narkoba, korupsi, plagiarisme, kecurangan dalam berbagai jenis ujian dan gejolak sosial. Keempat, persepsi publik yang menilai pendidikan selama ini terlalu menitikberatkan pada aspek kognitif, beban siswa yang terlalu berat, dan kurang bermuatan karakter (Sudjendro, 2014, p. 2).

Proses implementasi Kurikulum 2013 ini tidak serta-merta langsung diterapkan di seluruh sekolah di Indonesia, melainkan bertahap. Kurikulum ini pertama diterapkan pada sekolah-sekolah yang dahulu memiliki kelas SBI (sekolah bertaraf internasional). Ada beberapa sekolah Negeri yang ditunjuk oleh Dinas Pendidikan Kota Yogyakarta sebagai pilot project implementasi Kurikulum 2013, di antaranya adalah SMAN 1, SMAN 2, SMAN 3, dan SMAN 8 kota Yogyakarta. Empat sekolah tersebut hingga saat ini masih melaksanakan Kurikulum 2013, walaupun sekolah-sekolah lain di kota Yogyakarta yang baru menerapkan Kurikulum 2013 selama 1 semester kembali pada kurikulum 2006. Penghentian kurikulum ini dilandasi antara lain karena masih ada masalah dalam kesiapan buku, sistem penilaian, penataran guru, pendamping guru dan pelatihan kepala sekolah yang belum merata.

SMAN 2 dan SMAN 8 merupakan dua sekolah yang menjadi pilot proyek implementasi Kurikulum 2013 di kota Yogyakarta. Sebagai sekolah yang ditunjuk oleh Dinas Pendidikan untuk menjadi pilot proyek Kurikulum 2013, kedua sekolah tersebut pun mempersiapkan diri untuk melaksanakan kurikulum tersebut. Beberapa persiapan yang dilakukan oleh sekolah tersebut adalah persiapan secara internal sekolah dan persiapan mengikuti pelatihanpelatihan bagi pendidik dan tenaga kependidikan masing-masing sekolah. Pelatihanpelatihan Kurikulum 2013 bagi pendidik dan tenaga kependidikan terus dilakukan oleh pihak Dinas Pendidikan kota Yogyakarta, guna mampu melaksanakan kurikulum baru tersebut.

Proses implementasi Kurikulum 2013 di SMA N 2 Yogyakarta berjalan dengan baik karena di dukung oleh beberapa orang guru yang telah memiliki izin sebagai instruktur nasional implementasi Kurikulum 2013. Mereka itu adalah kepala sekolah dan wakil kepala sekolah bagian kurikulum. Begitu juga di SMA N 8 Yogyakarta, ada 3 guru yang sudah memiliki sertifikat instruktur nasional implementasi Kurikulum 2013. Ada-nya para guru yang telah memiliki sertifikat instruktur nasional implementasi 
Kurikulum 2013 sangat membantu un-tuk penerapannya di sekolah masing-masing.

Salah satu kunci keberhasilan implementasi Kurikulum 2013 adalah guru, karena guru merupakan perencana, pelaksana, dan pengembang kurikulum bagi kelasnya. Sekalipun guru tidak mencetuskan sendiri konsep-konsep tentang kurikulum, guru merupakan penerjemah kurikulum yang datang dari pusat. Gurulah yang mengolah, meramu kembali kurikulum. Peranan guru sangat penting dalam keberhasilan tujuan dari pendidikan, karena guru bukan hanya menilai perilaku dan prestasi belajar siswa dalam kelas, tetapi juga menilai implementasi kurikulum dalam lingkup yang lebih luas (Sukmadinata, 1997, p. 157). Oleh karena itu, guru sangat perlu dipersiapkan kemampuannya dalam mengajar guna menyukseskan implementasi $\mathrm{Ku}$ rikulum 2013.

Dalam rangka menyukseskan implementasi Kurikulum 2013, dan untuk mewujudkan Indonesia emas di ulang tahun yang ke 100 nanti, manajemen SDM, terutama guru harus diperbaiki, ditingkatkan kualitasnya agar menjadi guru profesional dan bermutu, jumlahnya harus dipenuhi, kesejahteraannya harus diperbaiki dan ditingkatkan, serta manajemennya harus dibenahi (Mulyasa, 2015, p. 14). Bell \& Rhodes (2002, p. 152) Bell dan Rhodes mengatakan 'The most valuable resource available in any school is its staff. Teachers and support staff make the most significant contribution to the success of any school."Maksudnya adalah sumber daya yang paling berharga yang tersedia di setiap sekolah adalah para stafnya. Guru dan staf pendukung membuat kontribusi yang paling signifikan untuk keberhasilan sekolah.

Menurut Chan (2010, p. 94) pengembangan guru adalah kunci sukses implementasi kurikulum:

According to models of curriculum implementation, the "mutual adaptation approach" usually works better than the "fidelity approach" in the literature of change, as adjustments and negotiations are allowed by curriculum developers and those who actually utilize The curriculum in schools or classrooms. It is particularly important that a teacher's involvement and participation are assumed to be active in the process of mutual adaptation. In The respect, teacher's professional development is key to successful curriculum implementation.

Menurut penjelasan di atas, berdasarkan model implementasi kurikulum, "pendekatan saling penyesuaian" biasanya bekerja lebih baik daripada "pendekatan ketaatan" dalam literatur perubahan, sebagai penyesuaian dan negosiasi diperbolehkan oleh pengembang kurikulum dan orangorang yang benar-benar memanfaatkan kurikulum di sekolah-sekolah atau kelas. Hal itu sangat penting bahwa keterlibatan dan partisipasi guru diasumsikan menjadi aktif dalam proses saling penyesuaian. Dalam hal ini, pengembangan profesional guru adalah kunci sukses untuk implementasi kurikulum.

Berdasarkan penelitian yang dilakukan oleh Hasanah (2015) tentang Evaluasi Implementasi Kurikulum 2013 pada SMA Pilot Project di Kota Yogyakarta diperoleh hasil penelitian bahwa implementasi Kurikulum 2013 sudah efektif dengan capaian rata-ratanya adalah $87,44 \%$. Indikator efektif implementasi Kurikulum 2013 dilihat dari ketercapaian pemahaman tujuan implementasi Kurikulum 2013 menunjukkan skor capaian $94,72 \%$ dengan rata-rata kesenjangan (discrepancy) 5,29\%. Pencapaian kompetensi yang dimiliki guru dalam implementasi Kurikulum 2013 menunjukkan kompetensi guru rata-ratanya adalah 90,02\%. Efektivitas metode pembelajaran Kurikulum 2013 yang diterapkan dalam implementasi Kurikulum 2013 menunjukkan rata-ratanya $80,29 \%$. Besarnya motivasi guru dalam implementasi Kurikulum 2013 menunjukkan capaian rata-rata $91,10 \%$. Hambatan bagi guru dalam implementasi Kurikulum 2013 menunjukkan komponen hambatan tersebut memiliki capaian rata-rata 70,61\%.

Nandi $(2015$, p. 1) dalam penelitiannya tentang pengaruh kepemimpinan kepala sekolah, profesionalisme guru, dan pelatihan guru terhadap implementasi Kurikulum 2013 di Sekolah Menengah Kejuruan Negeri kota Yogyakarta, bahwa hasil penelitiannya 
menunjukkan bahwa kepemimpinan kepala sekolah berpengaruh terhadap implementasi Kurikulum 2013 dengan sumbangan sebesar 11,94\%. Profesionalisme guru berpengaruh terhadap implementasi kurikulum dengan sumbangan sebesar $8,35 \%$. Pelatihan guru berpengaruh terhadap implementasi Kurikulum 2013 dengan sumbangan sebesar 3,79\%. Berdasarkan penelitian terebut ternyata pelatihan guru yang merupakan salah satu bentuk pengembangan kompetensi guru memiliki pengaruh yang kecil hanya sekitar 3,79\% saja. Maka peneliti menjadi tertarik untuk meneliti lebih mendalam tentang pengembangan kompetensi guru dari sudut pandang manajemen. Peneliti berasumsi mungkin ada kesalahan dalam pengelolaan kegiatan pengembangan tersebut, sehingga hanya berpengaruh kecil terhadap implementasi Kurikulum 2013 tersebut.

Berdasarkan data dan fenomena di atas, untuk menyukseskan implementasi Kurikulum 2013 harus dimulai dengan peningkatan kualitas guru, yang sampai saat ini masih banyak kendala dan tantangan yang dihadapi, terutama dalam pelaksanaan program pengembangan kualitas guru . Hal ini penting, karena kunci keberhasilan dalam implementasi kurikulum dan pembelajaran adalah kemampuan profesionalitas guru (Mulyasa, 2015, p. 13). Oleh karena itu, penelitian ini bertujuan untuk mendeskripsikan pola manajemen yang dilaksanakan oleh SMA Negeri 2 dan SMA Negeri 8 dalam melaksanakan program pengembangan kompetensi guru. Peneliti ingin melihat persiapan guru profesional dari sudut pandang manajemen, sehingga peneliti memiliki ketertarikan untuk melakukan penelitian yang lebih mendalam yang berkaitan dengan manajemen pengembangan kompetensi guru untuk implementasi Kurikulum 2013 di SMA pilot project kota Yogyakarta terutama yang berkaitan dengan perencanaan, pengorganisasian, pelaksanaan dan pengendalian program pengembangan kompetensi guru untuk implementasi Kurikulum 2013.

\section{Metode Penelitian}

Penelitian ini menggunakan pendekatan kualitatif dengan metode studi kasus. Menurut Yin (2014, p. 2) studi kasus merupakan bentuk penelitian ilmu sosial yang berfokus pada sebuah fenomena kontemporer, terutama ketika batas-batas antara fenomena dan konteks mungkin belum terlihat jelas. Selain itu penelitian studi kasus merupakan strategi yang cocok untuk penelitian yang pokok pertanyaannya berkenan dengan how atau why. Pada penelitian ini, kasus yang menjadi fokus penelitian adalah keberhasilan SMA Negeri 2 dan SMA Negeri 8 dalam melaksanakan program pengembangan kompetensi guru untuk implementasi Kurikulum 2013. Di sisi lain banyak sekolah Negeri di kota Yogyakarta yang memilih untuk tidak melanjutkan kembali implementasi Kurikulum 2013 di sekolah mereka.

Penelitian ini dilaksanakan mulai bulan Januari sampai dengan bulan April 2016. Adapun yang menjadi tempat penelitian adalah SMA Negeri 2 dan SMA Negeri 8 kota Yogyakarta. Subjek penelitian ini adalah SMA Negeri 2 dan SMA Negeri 8 kota Yogyakarta beserta seluruh bagian dan individu yang terlibat dalam kegiatan pengembangan kompetensi guru yaitu kepala sekolah, wakil kepala sekolah, kepala bagian tata usaha dan guru. Objek penelitian ini adalah manajemen pengembangan kompetensi guru untuk implementasi Kurikulum 2013 yang meliputi perencanaan, pengorganisasian, pelaksanaan serta pengendalian kegiatan pengembangan kompetensi guru.

Teknik pengumpulan data pada penelitian ini adalah dengan menggunakan observasi, penelusuran dokumen dan wawancara. Instrumen pengumpulan data dalam penelitian ini adalah peneliti sendiri. Peneliti adalah instrumen kunci yang disertai dengan instrumen pendukung lainnya seperti panduan observasi, pedoman wawancara, serta panduan dokumentasi.

Pengamatan atau observasi dilakukan langsung oleh peneliti terhadap subjek penelitian. Peneliti melakukan pengamatan 
dan melakukan pencatatan terhadap objek yang peneliti amati, yaitu suasana pembelajaran kelas, gedung dan sarana prasarana pembelajaran di sekolah, serta sumber daya manusia.

Dokumentasi dalam penelitian ini dengan mengumpulkan dokumen-dokumen yang berkaitan dengan penelitian seperti daftar guru dan karyawan, dokumen keorganisasian serta foto-foto kegiatan.

Wawancara dilakukan dengan kepala sekolah, wakil kepala sekolah bagian kurikulum serta guru-guru yang pernah mengikuti kegiatan pengembangan kompetensi. Hal tersebut dilakukan untuk mendapatkan informasi yang berkaitan dengan manajemen pengembangan kompetensi guru yang meliputi perencanaan, pengorganisasian, pelaksanaan dan pengendalian serta faktor-faktor yang mempengaruhinya.

Keabsahan data yang digunakan dalam penelitian ini yaitu derajat kepercayaan (credibility), ketergantungan (dependability) dan kepastian (confirmability). Pada penelitian ini menggunakan derajat kepercayaan dengan teknik trianggulasi, baik menggunakan trianggulasi metode maupun sumber data. Trianggulasi sumber dilakukan dengan membandingkan data informasi yang diberikan oleh kepala sekolah dan wakil kepala sekolah bagian kurikulum dengan data dari guru. Sedangkan trianggulasi metode dilakukan dengan membandingkan data hasil wawancara dengan catatan lapangan dan dokumentasi yang di dapat dari kepala bagian tata usaha. Selain itu, untuk menjamin keabsahan data wawancara dilakukan konfirmasi antara hasil wawancara dengan informan untuk memastikan kebenaran hasil wawancara (confirmability), yaitu dengan memberikan transkip hasil wawancara kepada informan untuk diberikan catatan, tambahan informasi, dan diberikan pengesahan/paraf.

Setelah data terkumpul, langkah selanjutnya yang peneliti lakukan adalah memaknai data atau analisis data. Analisis data yang peneliti lakukan adalah analisis induktif. Analisis tersebut dilakukan untuk menarik suatu kesimpulan terhadap hal-hal atau peristiwa-peristiwa dari data yang telah dikumpulkan melalui observasi, dokumentasi dan wawancara. Analisis data yang digunakan dalam penelitian ini adalah analisis model interaktif yang terdiri atas beberapa kegiatan di antaranya adalah pengumpulan data, reduksi dara, penyajian data, dan penarikan kesimpulan (Miles \& Huberman, 1994, p. 12).

\section{Hasil Penelitian dan Pembahasan}

Pengembangan sumber daya manusia merupakan salah satu bentuk dari kegiatan manajemen sumber daya manusia (Usman, 2014, p. 249). Pengembangan sumber daya manusia merupakan kegiatan yang berkesinambungan untuk mengembangkan kompetensi karyawan dan memotivasi mereka agar tujuan organisasi tercapai (Mahapatro, 2010, p. 254). Kegiatan pengembangan sumber daya manusia menjadi tanggung jawab organisasi untuk membekali orang-orang di dalam organisasi agar memiliki kompetensi yang memadai dalam rangka pencapaian tujuan organisasi.

Pengembangan kompetensi guru merupakan kegiatan berkelanjutan yang dilaksanakan oleh sekolah dan pemerintah dengan tujuan agar sekolah dapat melaksanakan Kurikulum 2013 dengan baik dan tepat sasaran. Sejak diberlakukannya penerapan Kurikulum 2013, sekolah yang terpilih menjadi pilot project kurikulum tersebut dengan giat melaksanakan pembekalan kepada para guru dan karyawan. SMA Negeri 2 dan SMA negeri 8 kota Yogyakarta menjadi sekolah pilot project Kurikulum 2013 di kota Yogyakarta. Sekolah tersebut telah melaksanakan Kurikulum 2013 sejak pertama kali diberlakukannya kurikulum tersebut hingga saat ini.

Bentuk kegiatan pengembangan kompetensi guru untuk implementasi Kurikulum 2013 yaitu berupa workshops, In House Training, Musyawarah Guru Mata Pelajaran (MGMP) serta studi lanjut. Menurut Priansa (2014, p. 155) metode yang paling penting dalam pengembangan sumber daya manusia adalah metode pendidikan (education) dan metode pelatihan (Training). Workshop, In House Training, Musyawarah Guru Mata 
Pelajaran (MGMP) merupakan bentuk pelatihan yang diperuntukkan bagi guru untuk meningkatkan kompetensinya. Sedangkan studi lanjut merupakan bentuk pendidikan bagi guru untuk meningkatkan kompetensinya. Hal ini sesuai dengan apa yang di sampaikan oleh Priansa (2014, p. 155) di atas yang menyatakan bahwa metode yang paling penting dalam pengembangan sumber daya manusia adalah metode pendidikan (education) dan metode pelatihan (Training). workshops, In House Training, Musyawarah Guru Mata Pelajaran (MGMP) merupakan bentuk pelatihan yang diperuntukkan bagi guru untuk meningkatkan kompetensinya. Sedangkan studi lanjut merupakan bentuk pendidikan bagi guru untuk meningkatkan kompetensinya.

Tujuan dari pengembangan kompetensi guru ini tidak lain adalah agar sekolah dapat menerapkan Kurikulum 2013 secara baik dan tepat. Sebagaimana yang disebutkan di atas, bahwa guru adalah faktor penting dalam implementasi Kurikulum 2013. Sehingga kegiatan pengembangan kompetensi tersebut sangat perlu untuk dilakukan. Hal ini sesuai dengan yang dijelaskan oleh Mahapatro (2010, p. 257) bahwa tujuan dari pengembangan SDMitu adalah untuk memberikan kesempatan dan kerangka kerja yang komprehensif untuk pengembangan SDM di dalam organisasi itu sendiri. Selain itu pengembangan SDM juga bertujuan untuk mengembangkan pikiran (Mindset) yang konstruktif serta kemampuan dan kinerja individu di dalam organisasi. Tujuan pengembangan kompetensi guru untuk Kurikulum 2013 di SMAN pilot Prospect kota Yogyakarta juga sesuai dengan apa yang disampaikan oleh Carrel (Widodo, 2015, p. 83) bahwa kegiatan tersebut bertujuan untuk meningkatkan kinerja karyawan, memperbaharui keterampilan kerja, menghindari keusangan manajerial serta memenuhi kebutuhan kepuasan pribadi.

Mempersiapkan guru yang kompeten untuk mengimplementasikan Kurikulum 2013 secara baik bukanlah hal yang mudah. Hal tersebut merupakan rangkaian proses yang harus di jalani oleh seluruh sivitas akademik sekolah, terutama guru. Proses yang baik membutuhkan pengelolaan yang baik. Kegiatan pengembangan kompetensi merupakan proses untuk menciptakan guru yang mampu mengimplementasikan Kurikulum 2013 dengan baik. Kegiatan ini perlu mendapatkan pengelolaan yang baik. Pengelolaan ini di awali dengan membuat rencana kegiatan yang tepat. Perencanaan kegiatan pengembangan kompetensi guru harus tersusun dengan baik sehingga kompetensi guru dapat meningkat dengan baik. Kegiatan pengembangan kompetensi guru diawali dengan membentuk tim kegiatan yang terdiri dari kepala sekolah, wakil kepala bagian kurikulum serta guru dan karyawan. Tim tersebut melakukan beberapa perencanaan, yaitu perencanaan yang berkaitan dengan materi pengembangan, narasumber, jenis pengembangan, anggaran hingga sarana dan prasarana yang mendukung kegiatan pengembangan tersebut. Perencanaan ini dilakukan dengan maksud agar kegiatan pengembangan dapat mencapai tujuan yang diinginkan yaitu terciptanya guru yang kompeten untuk menerapkan Kurikulum 2013.

Perencanaan kegiatan pengembangan kompetensi guru dilakukan dengan mempelajari Peraturan-peraturan Menteri Pendidikan Nasional tentang Kurikulum 2013. Kegiatan perencanaan pengembangan kompetensi guru yang dilakukan di SMAN 2 dan 8 tersebut sesuai dengan apa yang dikatakan oleh Griffin (1990, p. 161), yaitu "Planning is a comprehensive process that includes setting goals, developing plans, and related activities." Maksudnya adalah bahwa perencanaan merupakan proses yang komprehensif yang mencakup 3 hal kegiatan berikut yaitu menetapkan tujuan, mengembangkan rencana, dan kegiatan yang terkait. Proses penetapan tujuan yang dilakukan oleh sekolah dalam kegiatan pengembangan kompetensi ialah dengan melihat Peraturan-peraturan Menteri Pendidikan Nasional tentang implementasi Kurikulum 2013, di antaranya ialah berkaitan dengan pembelajaran dan penilaian.

Hal lain dalam perencanaan sebagaimana yang diungkapkan oleh Griffin di atas adalah mengembangkan rencana. Dalam 
proses perencanaan kegiatan pengembangan kompetensi guru untuk implementasi Kurikulum 2013 tim pelaksana melakukan kajian tentang peraturan menteri pendidikan nasional terkait dengan Kurikulum 2013. Berdasarkan kajian tersebut, tim mengembangkan rencana dengan mempelajari mendalam peraturan tersebut. sehingga didapatlah oleh tim bahwa pembelajaran saintifik dan penilaian autentik menjadi hal yang sangat wajib di kuasai oleh guru.

Namun menurut Noe (2005, p. 6), proses desain pelatihan di awali dengan melakukan penilaian kebutuhan. Kegiatan tersebut terdiri atas analisis organisasi, analisis personal dan analisis tugas. Serta memastikan para peserta siap untuk mengikuti pelatihan baik sikap, motivasi dan kemampuan dasarnya. Kegiatan perencanaan pengembangan kompetensi guru untuk implementasi Kurikulum 2013 di SMA Negeri Pilot Project Yogyakarta belum melaksanakan proses tersebut. Pihak sekolah mengirimkan atau melaksanakan langsung para guru untuk mengikuti kegiatan pengembangan tanpa melakukan penilaian terlebih dahulu terhadap guru.

Pengembangan kompetensi guru akan menghasilkan kompetensi guru yang baik jika apa yang telah direncanakan sebelumnya berjalan sesuai dengan perencanaan. Agar apa yang telah direncanakan dapat berjalan sesuai dengan rencana, maka harus ada pembagian tugas yang jelas. Hal ini dalam manajemen disebut dengan pengorganisasian atau organizing.

Kegiatan pengembangan kompetensi guru dilakukan dengan membentuk tim. Tim tersebut terdiri atas kepala sekolah, wakil kepala sekolah kurikulum dan guru serta karyawan. Ketua kegiatan pelaksanaan pengembangan kompetensi guru adalah kepala sekolah, sedangkan yang bertindak sebagai sekretaris adalah wakil kepala sekolah bagian kurikulum, guru dan karyawan masuk ke dalam anggota. Pada bagian keanggotaan, beberapa guru dan karyawan bertugas sebagai bagian konsumsi, bagian perlengkapan serta bagian sarana dan prasarana pengembangan kompetensi guru.
Setelah kegiatan pengorganisasian dilakukan oleh tim pelaksana, maka kegiatan selanjutnya adalah melaksanakan apa yang telah di rencanakan dan diorganisasikan. Pelaksanaan kegiatan pengembangan kompetensi guru akan dapat berjalan dengan baik jika semua komponen dalam kegiatan pengembangan tersebut berjalan dengan baik. Agar komponen tersebut berjalan atau melaksanakan apa yang telah direncanakan, maka membutuhkan pengarah atau penggerak. Penggerak dalam hal ini adalah kepala sekolah.

Pelaksanaan pengembangan kompetensi sudah berjalan $100 \%$ untuk program kegiatan yang di adakan oleh pemerintah dan dilakukan secara bertahap. Bentuk kegiatan pengembangan kompetensi guru tersebut sebagaimana yang telah dijelaskan di atas juga yaitu Workshop, Pelatihan dan pendidikan, Pelatihan dan pengembangan, In house Training, MGMP serta studi lanjut. Materi yang di bahasa adalah sesuai dengan Peraturan-peraturan Menteri Pendidikan Nasional tentang Kurikulum 2013 terutama PERMENDIKNAS No. 103 dan 104 yaitu tentang pembelajaran saintifik dan penilaian autentik. Materi tersebut di sampaikan oleh narasumber yang menguasai materi, yaitu mereka yang telah memiliki sertifikat sebagai instruktur nasional Kurikulum 2013.

Pengembangan kompetensi guru yang bertujuan untuk implementasi Kurikulum 2013 hakikatnya memuat dua hal utama pengembangan skill dan mindset pembelajaran. Program pengembangan yang dilaksanakan untuk mengembangkan kompetensi tersebut harus tepat. Pengembangan skill erat kaitannya dengan program Training atau pelatihan, sedangkan mindset erat kaitnya dengan pendidikan atau pembelajaran. Sebagai mana yang diuraikan oleh Masadeh (2012, p. 66) yang menyarankan bahwa ketepatan penggunaan istilah pelatihan, pengembangan, pendidikan dan pembelajaran dalam program pengembangan SDM sangat perlu di perhatikan. Seorang manajer harus memilih metode, mempertimbangkan biaya, isi program, fasilitas, kapabilitas peserta, serta prinsip- 
prinsip belajar (Kaswan \& Akhyadi, 2015, p. 371).

Selain itu, peningkatan profesional guru dapat dilakukan dengan program portofolio guru. Menurut Wilcox (1997, p. 170), portofolio guru tidak hanya berguna untuk penilaian diri, tetapi juga untuk penembangan profesional diri mereka sendiri. Hal ini yang belum dilaksanakan dalam program pengembangan kompetensi guru untuk implementasi Kurikulum 2013. Program portofolio guru dirasa berat untuk dilakukan oleh guru itu sendiri, mengingat sistem pendidikan yang diterapkan saat ini menuntut guru untuk melakukan persiapan pembelajaran yang matang dari pada proses pembelajaran di kelas. Namun bukan berarti tidak bisa. Pada kenyataannya ada beberapa guru yang menerapkan ini untuk mereka sendiri, walaupun tidak ada tuntutan secara aturan di sekolah.

Selanjutnya menurut Griffin (1990, p. 11) Fungsi arahan/kepemimpinan terdiri atas 4 kegiatan yang berbeda, yaitu memotivasi para pegawai untuk terus bekerja dan berusaha, aspek-aspek arahan/kepemimpinan, berurusan dengan proses antar pribadi, kelompok, dan konflik dan yang terakhir adalah komunikasi yang merupakan komponen yang paling signifikan dalam kepemimpinan. Berdasarkan pemaparan hasil penelitian bahwa fungsi pengarahan belum seluruhnya nampak pada kegiatan pengembangan kompetensi guru tersebut. baru hanya beberapa saja yang tampak, yaitu aspek motivasi saja. Aspek yang lain tidak tampak pada kegiatan pengembangan tersebut karena mungkin tidak terjadi atau tidak ada. Namun bukan berarti pelaksanaan kegiatan pengembangan tersebut gagal atau kurang baik, akan tetapi karena para anggota sudah berjalan dengan baik sehingga tidak memerlukan arahan-arahan yang menuntut pemimpin untuk memberikan arahan secara terus menerus.

Berdasarkan kajian dokumentasi peneliti, baik di SMAN 2 maupun SMAN 8 peneliti menemukan ada 5 guru yang sedang menjalani Studi lanjut. Sedangkan untuk SMA Negeri 8 Yogyakarta hanya satu guru yang melanjutkan studi lanjut pada jenjang Strata 3 di UNY. Studi lanjut merupakan usaha sekolah untuk mengembangkan kompetensi guru. Menurut Noe (2005, p. 266) bahwa salah satu bentuk pengembangan adalah pendidikan formal. Pendidikan formal yang dimaksud adalah studi lanjut ke jenjang pendidikan yang lebih tinggi. Pendidikan formal ini akan membawa perubahan permanen terhadap pribadi guru. Terutama terkait dengan perubahan Mindset guru terhadap Kurikulum 2013 ini. Bahkan menurut Johnnie (1993, p. 8) pendidikan formal membuat karyawan lebih berpengetahuan dalam seni memotivasi bawahan di tempat kerja, membuat karyawan lebih baik dalam merancang pekerjaan dan lain sebagainya. Maka dapat kita pahami bahwa pendidikan formal adalah pengembangan yang paling baik, baik untuk pekerja itu sendiri maupun untuk organisasi secara keseluruhan. . Studi lanjut perlu direncanakan dengan baik.

Jika pelatihan dan pengembangan merupakan proses untuk memperbarui pengetahuan, keterampilan dan kemampuan karyawan untuk meningkatkan kinerja pekerjaan mereka, maka pelatihan dan pengembangan harus dievaluasi (Naris \& Ukpere, 2012, p. 11861). Pelaksanaan dan arahan pengembangan kompetensi guru telah selesai dilaksanakan. Maka langkah selanjutnya atau akhir adalah mengetahui apakah kegiatan tersebut bisa mencapai tujuan yang telah di buat sebelumnya. Hal ini dapat diketahui dengan melaksanakan fungsi manajemen yang paling akhir yaitu pengendalian dan evaluasi. Fungsi ini dilakukan untuk mengetahui tingkat keberhasilan dan penyerapan program terhadap peserta kegiatan pengembangan. Keberhasilan kegiatan akan tampak jika dibandingkan dengan standar yang sebelumnya telah di buat.

Pengawasan/pengendalian dan evaluasi pengembangan kompetensi guru untuk implementasi Kurikulum 2013 di SMAN pilot project kota Yogyakarta di lakukan dalam bentuk pendampingan, pemantauan dan supervisi. Kegiatan pendampingan dilakukan oleh guru pendamping. Guru pendamping adalah guru yang telah di tunjuk 
untuk melakukan kegiatan pendampingan terhadap guru yang baru saja mengikuti kegiatan pengembangan kompetensi. Pendampingan dilakukan dengan cara silang antar sekolah. Selain itu, guru pendamping juga masuk langsung ke dalam kelas guru yang sedang di dampingi. Sehingga guru pendamping akan mengetahui, sampai mana kemampuan guru tersebut setelah mendapatkan pelatihan atau pengembangan.

Selain pendampingan, pengendalian da pengawasan kegiatan pengembangan kompetensi guru juga di lakukan dengan supervisi. Menurut Drake, Meckler, \& Debra (2002, p. 151) bahwa supervisor memiliki tanggung jawab secara institusional untuk menilai proses yang berjalan pada organisasinya serta untuk membuat perbaikan yang akan menyeimbangkan tujuan pengembangan individu dan organisasi. Supervisi dilakukan oleh kepala sekolah terhadap guru-guru yang ada di sekolahnya masing-masing. Pada beberapa sekolah, supervisi kepala sekolah dilakukan secara terjadwal. Pada waktu-waktu tertentu, kepala sekolah akan masuk ke dalam kelas guru yang akan di supervisi. Objek kegiatan supervisi ini adalah administrasi kelas/ pembelajaran seperti RPP, silabus, program tahunan dan semester, bahan ajar, media dan lain sebagainya. Selain itu, metode guru dalam pembelajaran juga tidak lepas dari kegiatan supervisi yang dilakukan oleh kepal sekolah.

Berkaitan dengan supervisi, ditinjau dari kegiatan supervisi, dapat dibedakan menjadi 2 yakni supervisi akademik dan supervisi administrasi (Arikunto, 2006, p. 5). Supervisi akademik adalah supervisi yang objeknya menitik beratkan pengamatan pada masalah akademik, yaitu yang langsung berada dalam lingkup kegiatan pembelajaran yang dilakukan oleh guru untuk membantu siswa ketika "sedang dalam proses belajar atau mempelajari sesuatu". Supervisi administrasi adalah supervisi yang objeknya menitik beratkan pengamatan pada aspek-aspek administrasi yang berfungsi sebagai pendukung dan memperlancar terlaksananya proses pembelajaran. Supervisi yang dilakukan oleh kepala sekolah tersebut di atas terhadap guru pelaksana Kurikulum 2013 termasuk pada jenis supervisi administratif. Penguasaan guru terhadap kelas yang di ajarnya dan cara guru menyampaikan materinya menjadi fokus pengamatan kepala sekolah terhadap guru yang sedang diawasinya.

Menurut Noe (2005, p. 172) evaluasi Training melibatkan evaluasi formatif dan sumatif. evaluasi formatif mengacu pada evaluasi yang dilakukan untuk meningkatkan proses pelatihan. Artinya, evaluasi formatif bantuan untuk memastikan bahwa: Program pelatihan adalah terorganisasi dengan baik dan berjalan lancar. Peserta pelatihan belajar dan puas dengan program ini. Sedangkan evaluasi sumatif mengacu pada evaluasi yang dilakukan untuk menentukan sejauh mana peserta telah berubah sebagai akibat dari berpartisipasi dalam program pelatihan. Evaluasi formatif adalah evaluasi untuk program pelatihan dan pengembangan yang di gunakan dalam kegiatan pengembangan kompetensi guru. Kegiatan tersebut diwujudkan dengan penyebaran angket kepuasan terhadap peserta untuk mengukur tingkat kepuasan peserta terhadap program yang dijalankan/digunakan. Sedangkan evaluasi sumatif dilakukan dalam bentuk pengendalian dan pengawasan serta supervisi kepala sekolah dan guru pendamping terhadap guru yang sedang berada pada masa pendidikan dan pelatihan dengan melihat langsung guru tersebut melaksanakan praktek mengajar.

Manajemen pengembangan kompetensi guru tidak lepas dari faktor-faktor yang mempengaruhinya, baik faktor pendukung maupun faktor penghambat. Faktorfaktor yang mempengaruhi tersebut sejatinya ada pada setiap kegiatan manajemen. Faktor pendukung pengembangan kompetensi guru untuk implementasi Kurikulum 2013 di SMAN pilot project kota Yogyakarta antara lain yaitu, pertama, adanya guru yang sudah menjadi instruktur Nasional implementasi Kurikulum 2013. Kedua, semangat guru yang tinggi untuk mengikuti kegiatan pengembangan. Ketiga, adanya anggaran dari sekolah untuk melaksanakan kegiatan pengembangan kompetensi guru. 
Selain faktor pendukung, pengembangan kompetensi guru juga tidak lepas dari adanya faktor-faktor penghambat. Faktor penghambat pengembangan kompetensi guru untuk implementasi Kurikulum 2013 yaitu, pertama, tidak adanya insentif untuk para peserta kegiatan. Kedua, kendala teknis seperti Proyektor rusak, masih adanya guru yang kurang lihai mengoperasikan laptop atau komputer. Ketiga, penentuan waktu pelaksanaan agar tidak mengganggu KBM siswa di sekolah. Penentuan waktu pelaksanaan menjadi sangat sulit bagi tim pelaksana untuk mengatur jadwal kegiatan, mengingat para guru memiliki kesibukan masing-masing baik yang berkaitan dengan kegiatan akademik maupun non-akademik seperti keluarga.

Upaya yang dapat dilakukan untuk mengatasi penghambat kegiatan tersebut yaitu, yang dilakukan oleh kepala sekolah dalam mengatasi hambatan peningkatan kompetensi guru yaitu dengan memfasilitasi dan memberikan kesempatan yang luas untuk melaksanakan pengembangan profesi, sedangkan upaya dalam mengatasi hambatan waktu pelatihan dengan membuat jadwal pengganti bagi guru yang diikutsertakan ke pelatihan, membuat jadwal tersendiri di luar jam pembelajaran (Ristiyani \& Wijayanti, 2014, p. 231). Sedangkan Upaya para guru dalam mengatasi hambatan di antaranya dengan melanjutkan ke Strata-2, keikutsertaan dalam berbagai pelatihan dan kegiatan ilmiah. Sedangkan upaya dalam mengatasi hambatan waktu pelatihan yang bersamaan dengan jam mengajar bahwa antara guru saling menukar jadwal mengajar. Alternatif selain tukar jadwal mengajar, yang dilakukan adalah memberikan tugas ke siswa yang tidak memberatkan guru lain.

Faktor lain yang mendukung program pengembangan kompetensi guru ini adalah motivasi yang tinggi dari kepala sekolah kepada para guru untuk mengikuti program tersebut. sebagaimana yang disampaikan oleh Tharenou (2001, p. 619) berdasarkan hasil penelitiannya yang menyarankan bahwa dukungan dari pemimpin adalah faktor kunci keikutsertaannya para guru terhadap program pengembangan.
Kepala sekolah perlu mendorong para guru untuk mengikuti dan membantumereka mengembangkan dan menggunakan keterampilan yang diperoleh dari program pengembangan tersebut. oleh karena itu, supervisi dan pendampingan setelah program pengembangan dilaksanakan adalah sangat perlu dilaksanakan.

Berdasarkan penelitian Syakir \& Pardjono (2015, p. 238), bahwa kepemimpinan kepala sekolah, motivasi kerja dan budaya organisasi berpengaruh secara signifikan terhadap peningkatan kompetensi guru SMA. Besar pengaruhnya yaitu sebesar 11,7 $\%$. Hal tersebut sesuai dengan hasil penelitian peneliti sendiri, bahwa kepala sekolah sebagai perencana kegiatan pengembangan kompetensi sangat berpengaruh terhadap peningkatan kompetensi guru. Kepemimpinan dalam organisasi adalah kunci dari keberhasilan pencapaian tujuan organisasi itu sendiri. Pemimpin sebagai perencana, penggerak, pelaksana, pembuat keputusan serta pengendali program kegiatan yang dilaksanakan.

\section{Simpulan}

Berdasarkan hasil penelitian dan pembahasan disampaikan simpulan sebagai berikut. Manajemen pengembangan kompetensi guru untuk implementasi Kurikulum 2013 dilakukan dengan beberapa proses yaitu, perencanaan pengembangan kompetensi guru untuk implementasi Kurikulum 2013 diawali dengan mengkaji Peraturan-peraturan Menteri Pendidikan Nasional tentang Kurikulum 2013 serta sekolah mempersiapkan anggaran untuk pelaksanaan kegiatan. Pengorganisasian pengembangan kompetensi guru untuk implementasi Kurikulum 2013 dilakukan dengan pembentukan team pelaksana oleh kepala sekolah. Dalam hal tersebut, kepala sekolah sebagai ketua team, wakil kepala sekolah bagian kurikulum sebagai wakil ketua pelaksana, serta beberapa guru dan karyawan menjadi anggota. Kepala sekolah mendistribusikan tugas dan pekerjaan kepada team sehingga kegiatan dapat berjalan dengan baik. 
Pelaksanaan dan pengarahan pengembangan kompetensi guru untuk implementasi Kurikulum 2013 dilakukan dengan menentukan jenis kegiatan pengembangan kompetensi guru. Bentuk kegiatan pengembangan kompetensi guru untuk implementasi Kurikulum 2013 adalah Workshop, pelatihan dan pengembangan, Pendidikan dan Pelatihan, In house Training, MGMP, serta studi lanjut. Pengarahan dilakukan oleh kepala sekolah dengan memberi motivasi kepada anggota agar bekerja dengan baik. Pengendalian pengembangan kompetensi guru untuk implementasi Kurikulum 2013 dilakukan pendampingan dan supervisi.

Faktor pendukung pengembangan kompetensi guru adalah pertama, adanya guru yang sudah menjadi instruktur nasional implementasi Kurikulum 2013. Kedua, semangat guru yang tinggi untuk mengikuti kegiatan pengembangan. Ketiga, adanya anggaran dari sekolah untuk melaksanakan kegiatan pengembangan kompetensi guru. Sedangkan Faktor penghambatnya adalah pertama, tidak adanya insentif untuk para peserta kegiatan. Kedua, kendala teknis seperti Proyektor rusak, masih adanya guru yang kurang lihai mengoperasikan laptop atau komputer. Ketiga, penentuan waktu pelaksanaan agar tidak mengganggu KBM siswa di sekolah.

Berdasarkan simpulan dari hasil penelitian dapat diberikan saran yaitu Kepala sekolah sebagai pemeran utama dalam kegiatan pengelolaan program pengembangan kompetensi guru di sekolah. Kepala Sekolah terlibat dalam setiap proses kegiatan mulai dari perencanaan, pengorganisasian, pelaksanaan hingga pengendalian kegiatan. Maka kepala sekolah diharapkan mampu menggerakkan setiap lini proses kegiatan pengembangan tersebut. Dalam proses perencanaan, kepala sekolah harus melakukan penilaian kebutuhan terhadap guru terutama yang berkaitan dengan implementasi Kurikulum 2013, seperti strategi pembelajaran dan penilaian. Dalam proses pelaksanaan, kepala sekolah harus mampu menggerakkan atau memotivasi bawahan atau tim pelaksana sehingga mereka dapat bekerja sesuai dengan tugas masing-masing. Dalam proses pengendalian, kepala sekolah memiliki jadwal supervisi yang jelas dan melaksanakannya secara berkelanjutan serta melakukan tindak lanjut terhadap hasil supervisi yang diperolehnya. Beberapa hal tersebut harus dapat berjalan dengan baik sehingga tujuan pengembangan kompetensi guru dapat tercapai dengan baik dan implementasi kurikulum dapat berjalan dengan lancar.

Selain kepala sekolah, Guru sebagai peserta pengembangan harus dapat memanfaatkan fasilitas yang diberikan oleh sekolah tersebut dengan menghadiri setiap kegiatan peningkatan kualitas diri yang di selenggarakan oleh sekolah atau dinas terkait. Bila memungkinkan, lanjutkan pendidikan pada tingkat tinggi. Karena pada hakikatnya program tersebut adalah untuk diri guru sendiri sebagai penunjang dalam melaksanakan tugas dan amanat negara.

\section{Daftar Pustaka}

Arikunto, S. (2006). Dasar-dasar supervisi. Jakarta: PT.Rineka Cipta.

Bell, L., \& Rhodes, C. (2002). The skills of primary school management. London: Routledge.

Chan, J. K. S. (2010). Teachers' responses to curriculum policy implementation: olonial constraints for curriculum reform. Educational Research Policy Practice, 9, 93-106.

Drake, B. H., Meckler, M., \& Debra, S. (2002). Transitional ethics: Responsibilities of supervisors for supporting employee development. Journal of Business Ethics, 38, 141-155.

Griffin, R. W. (1990). Management. Boston: Houghton Mifflin Company.

Hasanah, U. N. (2015). Evaluasi implementasi Kurikulum 2013 pada SMA pilot project di Kota Yogyakarta. Thesis. Unpublished. Universitas Negeri Yogyakarta.

Johnnie, P. B. (1993). Formal education: a paradigm for human resource 
development in organization. International Journal of Education Management, 7, 4-8.

Kaswan, \& Akhyadi, A. S. (2015). Pengembangan sumber daya manusia: dari konsepsi, paradigma, dan fungsi sampai aplikasi. Bandung: Alfabeta.

Mahapatro, B. B. (2010). Human resource management. New Delhi: New Age International Publisher.

Masadeh, M. (2012). Training, education, development and learning: What is the difference? European Scientific Journal, 8(10), 62-68.

Miles, M. B., \& Huberman, A. M. (1994). Qualitative data analysis: an expanded source book. Thousand Oaks: Sage Publications, Inc.

Mulyasa, H. E. (2015). Guru dalam implementasi Kurikulum 2013. Bandung: Remaja Rosdakarya.

Nandi, R. A. (2015). Pengaruh kepemimpinan kepala sekolah, profesionalisme guru, dan pelatihan guru terhadap implementasi Kurikulum 2013 di sekolah menengah kejuruan negeri kota Yogyakarta. Thesis. Unpublished. Universitas Negeri Yogyakarta.

Naris, S. N., \& Ukpere, W. I. (2012). Evaluation of human resource development and training at a higher educational institution in Namibia. African Journal of Business Management, 6, 11859-11864.

Noe, R. A. (2005). Employee training and development (3rd ed.). New York: McGraw-Hill.

Priansa, J. D. (2014). Perencanaan $\mathcal{E}$ pengembangan sumber daya manusia. Bandung: Alfabeta.
Ristiyani, R., \& Wijayanti, W. (2014).

Peningkatan kompetensi guru sekolah dasar Budi Mulia Dua Seturan, Depok, Sleman. Jurnal Akuntabilitas Manajemen Pendidikan, 2(2), 217-232. https:// doi.org/10.21831/amp.v2i2.2 450

Sudjendro, H. (2014). Siap menyongsong Kurikulum 2013. Yogyakarta: Gava Media.

Sukmadinata, N. S. (1997). Pengembangan kurikulum teori dan praktek. Bandung: PT Remaja Rosdakarya.

Syakir, M. J., \& Pardjono, P. (2015). Pengaruh kepemimpinan kepala sekolah, motivasi kerja, dan budaya organisasi terhadap kompetensi guru SMA. Jurnal Akuntabilitas Manajemen Pendidikan, 3(2), 226-240. https://doi.org/10.21831/amp.v3i2.6 339

Tharenou, P. (2001). The relationship of training motivation to participantion in training and development. Journal of Occupational and Organizational Psychology, 74, 599-621.

Usman, H. (2014). Manajeman: teori, praktik, dan riset pendidikan (4th ed.). Jakarta: PT Bumi Aksara.

Widodo, S. E. (2015). Manajemen pengembangan sumber daya manusia (Yogyakarta). Pustaka Pelajar.

Wilcox, B. L. (1997). The teacher's portofolio: an essential tool for professional development.

International Reading Association, 51(2), 170-173.

Yin, R. K. 1941-. (2014). Case study research: design and methods. London: Sage Publication. 